\title{
SOME FACTORS AFFECTING THE DAMAGE OF POTATO TUBERS DURING HARVEST
}

\author{
Arafa, G. K.*
}

\section{ABSTRACT}

This study investigated the effect of some factors affecting the damage of potato tubers during harvesting using potato harvesting machine with the chain, which harvest two lines. Three of the operating variables were studied. These factors included front speed of the machine, the depth of the cut and the vibration capacity of the machine sieve series. Experiments were carried out in a plantation in Wadi Al-Natroun Beheira Governorate in sandy clay soil and on a crop cultivated in 2018. It is a kind of King Edward with an oval shape. . The maximum percentage of raising tubers was $88.57 \%$ at forward speed $2 \mathrm{~km} / \mathrm{h}$. The minimum lift rate was $85.56 \%$ at forward speed $2.5 \mathrm{~km} / \mathrm{h}$. When the forward speed is increased from 1.5 to $2.5 \mathrm{~km} / \mathrm{h}$. Total damaged tubers increased from $2.88 \%$ to $4.63 \%$. . The potato damage index was 14.28 and 22.78 for forward speeds of 1.5 and $2.5 \mathrm{~km} / \mathrm{h}$, respectively. The depth of the drilling is increased from 14 to $22 \mathrm{~cm}$. The percentage of potato tubers raised increased from 70.92 to $97.25 \%$ respectively. The depth of drilling is increased from 14 to $22 \mathrm{~cm}$. Total damaged tubers decreased from $8.36 \%$ to $0.49 \%$. Where the index of potato damage decreased from 43.75 to 2.21 with an increase in depth of drilling from 14 to $22 \mathrm{~cm}$. The study also found that there was no significant effect of the sieve chain capacitance on tuber lift. The tubers raised were $85.34 \%$ and $89.65 \%$ for 20 and $25 \mathrm{~mm}$. respectively. The study found that the maximum tuber lift rate is $99.10 \%$ at a front speed of $1.5 \mathrm{~km} / \mathrm{h}$ with a depth of 22 and $25 \mathrm{~mm}$ screening range. The percentage of total damaged tubers was $0.60 \%$. Potato damage index was 3.40 for potatoes, 16.53 tons / fed. While the percentage of total tubers damaged $0.04 \%$ of potato productivity of 16.97 tons / fed at a speed of forward $2 \mathrm{~km} / \mathrm{h}$ with a depth of drilling of $22 \mathrm{~cm}$ and the capacity of the screening series 25 mm. In these operating factors. Potato damage index was 0.04. Tubing rate was $97.02 \%$ as a result of this study.

Res., Ag. Eng. Res. Institute., Ag. Res. Center. * 
The following operating factors are recommended: Forward speed to 2.5 $\mathrm{km} / \mathrm{h}$. Drilling depth $22 \mathrm{~cm}$. The sieve chain capacity is $25 \mathrm{~mm}$.

\section{INTRODUCTION}

$\mathrm{P}$ otato cultivation is widespread in Egypt, with about 325,000 fed. annually distributed in three varieties for local consumption and export with an average productivity of 8.5 tons / fed. There have been many previous researches and studies that have been done to find out the variables affecting potato tubers during the harvesting process in order to reach the optimal operation of the harvesting machine. Ismail (1991). Saadoun (1991) pointed to a number of points to be taken during the harvest process, which is the appropriate depth of the cutlery to reduce the occurrence of cutting or fragmentation of the tubers. The speed of the machine and the speed of the screen must be adjusted for the screening and degree of vibration so that some parts of the soil remain on the screening chains In the soils that can be easily sifted, the speed of the chains must be of a certain compatibility with the speed of the tractor. Harvesting should be avoided during the high temperature. The machine was tested at a frequency of $9.1,14$ and $18 \mathrm{~Hz}$ at 4 and $6 \mathrm{~mm}$, and forward speeds of $0.85,1.33$ and $2.12 \mathrm{~km} / \mathrm{h}$. The researchers found that the average tubers damage ranged between 1.25 and $8 \%$, and that the results of this developed machine were better than before the development. Abdel-geleal (1992) studied the factors that control the optimum performance of the potato harvesting machine by studying the relation between the ratios of the raised and damaged tubers, the front speed, the depth of the drill, the angle of penetration of the weapon, the speed of the rotary spindle, the number of separation blades and the distance of the overlap. Potato cultivation and tuberoses in soil. The machine was used to harvest two varieties of potatoes, Sponta and Diamond. The study showed that the lowest damage to tubers recorded with depth of $23 \mathrm{~cm}$ for both classes, and that the optimum depth $20 \mathrm{~cm}$. . It was also found that the optimal performance achieved at the speed of progress of $2.8 \mathrm{~km} / \mathrm{h}$, the depth of the cut tubers $20 \mathrm{~cm}$, and the angle of penetration of the weapon 18 degrees, and that the increase of the front speed from 1.8 to $3.8 \mathrm{~km} / \mathrm{h}$ increase the proportion of tubers raised and 
damaged for both categories. The researcher recommended using rotary spindle speed $501 / \mathrm{d}, 6$ sets of spindle blades, and $25 \mathrm{~cm}$ spacing between the spindle and the weapon. Abdel-Aal et al (2002) developed a potato harvester to harvest a single line and to work in Egyptian farms under light clay soil conditions. The researchers conducted a preliminary experiment of the machine to determine the appropriate distance between the weapon and the sieve chain at 8.5 and $11 \mathrm{~cm}$. The effect of the following geometrical factors is the front speed of machine 1.5, 2.3 and $3.1 \mathrm{~km} / \mathrm{h}$, the angle of the weapon of 14.8 and 20 degrees, the sieve series $2.41,3.13,3.85$ and $\mathrm{m} / \mathrm{s}$, and the angles of the separation device 5, 7 and 9 degrees, ) And buried (lost).The machine capacity and harvesting costs were also calculated and compared to manual harvesting. The researchers explained that the best engineering factors for the operation of the potato harvested machine, which achieved the highest percentage of tubers and the lowest percentage of lost and lost tubers is the front speed of the machine $2.3 \mathrm{~km} / \mathrm{h}$, the angle of the weapon 14 degrees, and the distance between arms and series $5 \mathrm{~cm}$, and the chain speed 2.41 meters / The tilt angle of the separation device is 7 degrees. Abdel-Maksoud et al (2004) developed a single-line potato harvester for harvesting and separating potatoes from the soil and transporting them out of the land harvested under sandy soils. . The researchers studied the engineering factors for the operation of the developed machine with the comparison of the machine before the development, namely the front speed 1.6, 2, 2.4 and $3 \mathrm{~km} / \mathrm{h}$, and the angle of penetration of arms 8, 14 and 20 degrees, at a depth of $20 \mathrm{~cm}$ on the loss and damage in the tubers and the cost and capacity, energy required and capacity and field efficiency. The researchers recommended the use of the improved harvesting machine because it has higher harvesting and cleaning efficiency as well as to reduce the loss in the tubers and because it is less expensive than the harvest machine before development, with the machine running at the front speed $2.4 \mathrm{~km} / \mathrm{h}$ and the penetration angle of the weapon 14 degrees and adjust the sieve separation by 8 degrees And running the sieve on speed $12 \mathrm{~m} / \mathrm{s}$. Emam (1999) developed and designed a harvest for the harvest of sugar potatoes suitable for Egyptian farms. The results showed that increasing the depth 
of the reduction from 25 to $30 \mathrm{~cm}$ and increasing the angle of the gun from 18 to 24 degrees and reducing the front speed of the machine from 3 to $2 \mathrm{~km} / \mathrm{h}$ increased the proportion of tubers raised above ground from 84.73 to 93 , The percentage of tubers from 82.4 to $91.73 \%$, the percentage of buried tubers decreased from 15.27 to $5.19 \%$, the proportion of tubers damaged decreased from 9.1 to $4.57 \%$ and the proportion of broken tubers decreased from 8, 5 to $3.7 \%$. Sayed et al. 1996 Study on the experimental harvesting of potatoes. The researchers explained that increasing the front speed of the machine from 3.5 to 5.5 $\mathrm{km} / \mathrm{h}$ in sandy soil and 2.5 to $4.5 \mathrm{~km} / \mathrm{h}$ in clay soil reduces the damage of tubers from 9,62 to $5.93 \%$, and reduce the proportion For tubers raised above ground from 11.72 to $9,24 \%$. The researchers also found that the lowest rate of tubers damage was $5.93 \%$ in sandy soils and $9.07 \%$ in clay soil. The best front speed of the machine in sandy soil is $5.5 \mathrm{~km} / \mathrm{h}$ and in clay soil $3.5 \mathrm{~km} / \mathrm{h}$. developed on experimental potato combine harvester with single-line harvesting. The aim of this study is to pest and evaluates some factors affecting the damage of potato tubers during harvest: These factors including front speed of the machine, depth of potato tubers vibration capacity of the primary series of the sieves. The damage of the potato tubers due to the changes in these factors were determined

\section{MATERIAL AND METHODS}

This research was carried out in a farm in Wadi El Natroun, El Beheira governorate, to study some factors affecting the damage of potato tubers during harvest under different variables of (forward speed, depth of digger, vibration).

\section{1- potato tubers used}

Potato tubers used in the research a kind of King Edward with an oval shape. The potato crop was harvested and the shape of the tuber can be determined according to the International Organization for Standards (handbook1983).

$$
f=\frac{l^{2}}{h \times t} \times 100
$$

Where: $f=$ Guide to the shape of the tuber

$1=$ Maximum length of the tuber $(\mathrm{mm})$ 


$$
\begin{aligned}
h & =\text { Maximum width of the tuber }(\mathrm{mm}) \\
\mathrm{t} & =\text { Maximum thickness of the tuber }(\mathrm{mm})
\end{aligned}
$$

\section{2-The harvester of potato}

The harvester of potato was connected with the Italian fiat agricultural tractor with a front drive, 100-900T / 15 fiat, $75 \mathrm{~kW}$ (100 hp), front tire size 12.4 -28PR, rear tire size 11.2R 48, front tire distance $140 \mathrm{~cm}$, distance between rear tires $150 \mathrm{~cm}$. It is characterized by the tractor that the tires with a small display allows easy movement between the lines of potato cultivation without the limits of mashed tubers. The potato digger with chain was used (Italian-made with a maximum load of $700 \mathrm{~kg}$ ). The potato harvester is suspended behind the tractor, and the potato harvester moves from the power socket of the tractor. The machine is used to harvest two lines with a width of 1.60 meters Fig (1) and table(1) present the future and specifications of the potato harvesting machine.

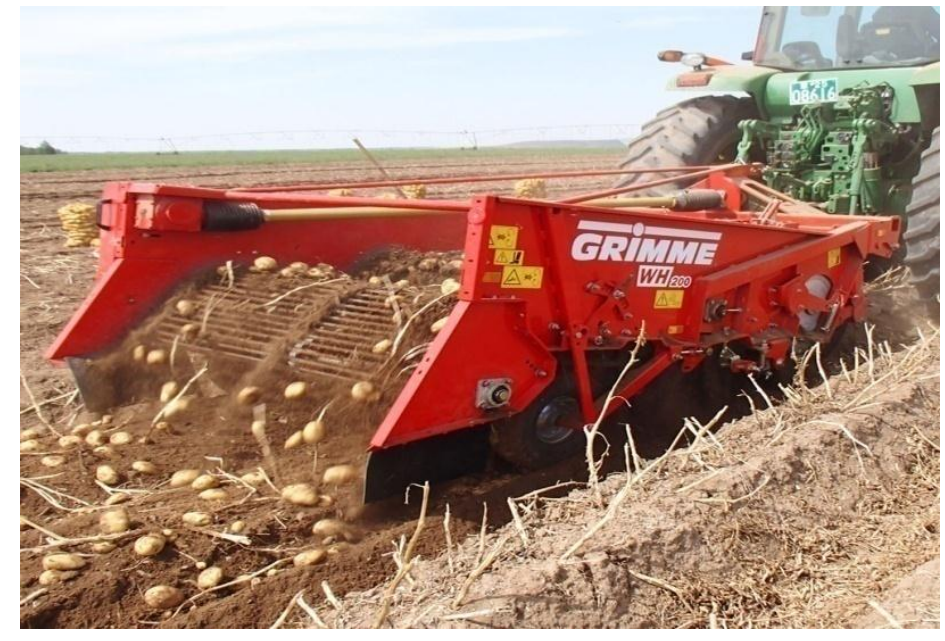

Fig.(1): Potato harvesting machine used in this research.

\section{3 -Method of conducting the experimental work:}

After the machine is connected with the tractor through the three clamping points, the machine was adjusted horizontally. So that the vertical of the machine is first set horizontally in the direction of the harvest by placing a water balance on the frame of the machine and raising or lowering the bottom grids until the horizontal of the machine is set. The horizontal of the machine is adjusted in the direction of the harvest by placing the water balance on the machine frame in a parallel 
direction to the movement of the machine and the tractor. By extending or shortening the length of the upper arm, the horizontal position of the harvest machine is adjusted.

Table (1): Technical specification and Characteristics of The Tractor, Potato digger and soil.

\begin{tabular}{|c|c|}
\hline Characteristics & Description \\
\hline \multicolumn{2}{|c|}{ Tractor } \\
\hline Brand & Fiat \\
\hline Model & $100-900 \mathrm{~T} / 15$ \\
\hline Engine power & $75 \mathrm{KW}$ \\
\hline Characteristics & Description \\
\hline \multicolumn{2}{|c|}{ Potato digger } \\
\hline Brand & Grimme \\
\hline Model & WH200 \\
\hline Number of rows & 2 \\
\hline Number of Conveyor & 2 \\
\hline Working width & $1.8 \mathrm{~m}$ \\
\hline Share shape & Trapezium \\
\hline Share width & $56 \mathrm{~cm}$ \\
\hline Hitching & Three point linkage \\
\hline \multicolumn{2}{|c|}{ soil } \\
\hline Kind & sandy \\
\hline
\end{tabular}

\section{4 - Speed of the screening chains}

The potato harvester was calibrated to determine the speed reduction ratio between the $\mathrm{P} T \mathrm{O}$ and the gearbox at the top of the machine through a lead roller to determine the speed of the screening chains. The following equations were used to find the speed of the primary and secondary series of the sieve unit depending on the rotational velocity of the PTO shaft, from the ratio of speed reduction between the speed of rotation of the shaft of the power outlet of the PTO and the rotation speed of the shaft of the gearbox (Ismail, 1991). The reduction was estimated at $1: 1.50$.

$$
\begin{aligned}
& \mathrm{i}=\frac{\mathrm{N}_{\mathrm{PTO}}}{\mathrm{N}_{1}} \\
& \frac{\mathrm{N}_{1}}{\mathrm{~N}_{2}}=\frac{D_{1}}{D_{2}}
\end{aligned}
$$

Where :

$\mathrm{i}=$ Speed reduction ratio 
$\mathrm{N}_{1}=$ Rotation speed of the steering wheel of the gearbox (rpm)

$\mathrm{N}_{\text {PTO }}=$ Rotation speed of the shaft of the power socket of the tractor $\mathrm{P}$ T O (rpm)

$\mathrm{N}_{2}=$ Rotational speed of primary coil pulley (rpm)

$\mathrm{D}_{1}=$ Diameter of the shaft of the shaft of the gearbox machine (mm)

$\mathrm{D}_{2}=$ Diameter of primary chain pulley $(\mathrm{mm})$

The linear velocity of the primary series V1 $(\mathrm{km} / \mathrm{h})$ could calculated from the following equation:

$$
V_{1}=\frac{6_{\pi} D_{2} N_{2}}{100000}
$$

The linear speed of the secondary series V2 $(\mathrm{km} / \mathrm{h})$ is calculated from the following equation

$$
\mathrm{V}_{2}=\frac{6_{\pi} \mathrm{D}_{4} \mathrm{~N}_{4}}{100000}
$$

The rotational speed of the gear wheel of the N4 secondary series can be calculated from the following relationship:

$$
\frac{\mathrm{N}_{4}}{\mathrm{~N}_{2}}=\frac{\mathrm{D}_{3}}{\mathrm{D}_{4}}
$$

Where:

$\mathrm{D}_{3}=$ Gear wheel diameter for primary series $(\mathrm{mm})$

$\mathrm{D}_{4}=$ Gear wheel diameter for secondary chain $(\mathrm{mm})$

$N_{4}=$ Rotary Speed for Secondary Gear Series (rpm)

The speed of the tractor engine was selected at 1100, 1300 and $1500 \mathrm{rpm}$. The speed values used on the potato harvester are 1.5 , 2and $2.5 \mathrm{~km} / \mathrm{h}$.

\section{5 -Tubers lifting percentage}

The rate of lift is estimated by the following equation (Abu Habajah and Al-Hayahi, 1999):

$$
\text { Lift }=\frac{\mathrm{w}_{1}}{\mathrm{~W}_{1}+\mathrm{W}_{2}} \times 100
$$

Where: $\mathrm{W}_{1}=$ Tubers lifting by machine $(\mathrm{g})$

$\mathrm{W}_{2}=$ mass of buried tubers in soil $(\mathrm{g})$ 


\section{6 -Percentage of total damage}

The total damage rate for potato tubers (D) is estimated from the following equation (Abdel-geleal (1992)

$$
\mathrm{D}=\frac{W_{4}}{\mathrm{~W}_{3}+\mathrm{W}_{4}} \times 100
$$

$$
\mathrm{w}_{3}=\text { mass of sound tubers }(\mathrm{g}) \mathrm{w}_{4}=\text { mass of damaged tubers }(\mathrm{g})
$$

\section{7-Potato tubers damage coefficient}

Potato tubers damage coefficient can be calculated from the demand equation

$$
\text { d. } i=1 x_{1}+3 x_{2}+7 x_{3}
$$

d.i =Potato tubers damage coefficient

$\mathrm{X}_{1}=$ The percentage of tuberous tubers is superficial

$\mathrm{X}_{2}=$ Proportion of tubers that are damaged and have no internal damage $\mathrm{X}_{3}=$ The proportion of broken tubers is deeply broken .

\section{RESULTS AND DISCUSSION}

\section{1-Effect of the forward speed of the harvesting machine on potato tubers.}

Fig. (2) shows the amount of harvested potatoes and buried in the soil and the proportion of potatoes tubers at different studied forward speeds. The effect of the forward speed on the quantity of potatoes harvested and buried potatoes. Showed that the quantity of potatoes shredded increased at the second speed and decreased at the third speed to give 13.79 tons / fed. It has noted that the amount of harvested potatoes between 13.0158 tons / fed for the first speed and 14.78 tons / fed for the second speed. There is an effect of the first speed and the second speed, while there is no impact of the third speed on the amount of potatoes shredded. Fig.( 2) shows that there is no effect of the forward speed of the machine on the amount of buried in the soil. It is noticed that with the increase in speed, the amount of buried potatoes increases. The amount of buried potatoes in the soil ranged between 1.659 tons / fed for the first speed and 2.121 ton / fed for the third speed .Fig. (3) Shows the impact of the forward speed of the machine on the proportion of potatoes. When the forward speed of 
the machine increased from $1.5 \mathrm{~km} / \mathrm{h}$ to $2 \mathrm{~km} / \mathrm{h}$, the rate of tuber reduction increased from $88.34 \%$ to $88.5 \%$ and decreased at the third speed $2.5 \mathrm{~km} / \mathrm{h}$ to $85.5 \%$. Fig. (4) Shows that there is a significant difference between the effect of the forward speeds of the machine on the percentage of total damage, as the increase in speed, the total damage to tubers increases. At the first speed the percentage of total damage was $2.88 \%$, while the third speed resulted in the highest total damage rate of $4.63 \%$. Fig. (4) Shows the effect of the forward speed of the harvesting machine on the percentage of shallow tuberous tubers. Fig.(4) shows that the proportion of tuberous tubers is superficial for the first two stages $0.27 \%$ and the second $0.28 \%$ is low, compared to the third speed which gave the highest percentage of superficial tuberous tubers $0.83 \%$. Fig. (4) Shows the effect of the forward speed of the machine on the rate of tubers. The percentage of tubers that have been rotated ranged between $1.06 \%$ for the first speed and $1.17 \%$ for the second speed. Fig.(4) shows that when the forward speed of the machine The proportion of broken tubers increases, The percentage of broken tubers ranged between $1.55 \%$ for the first speed and $2.64 \%$ for the third speed.

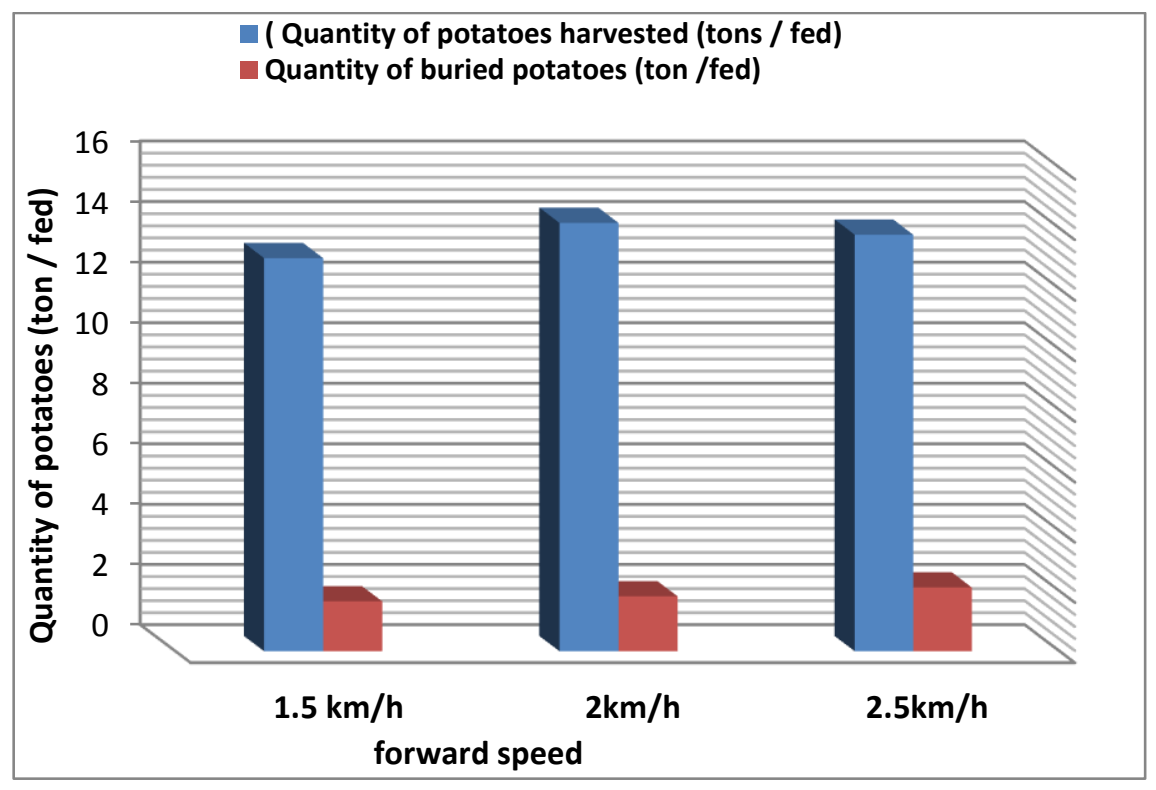

Fig. (2) Effect of the front speed of the machine on the proportion of potatoes and the amount of buried potatoes in the soil 


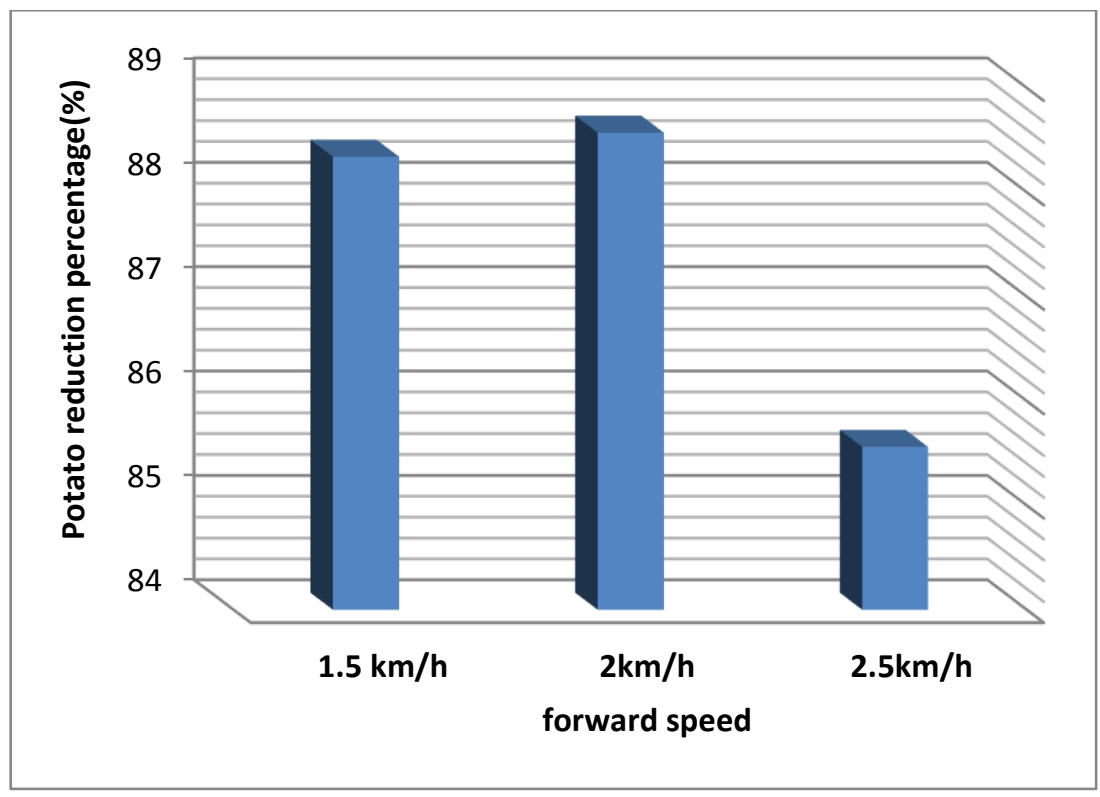

Fig. (3) Effect of the forward speed of the machine on the Potato reduction percentage.

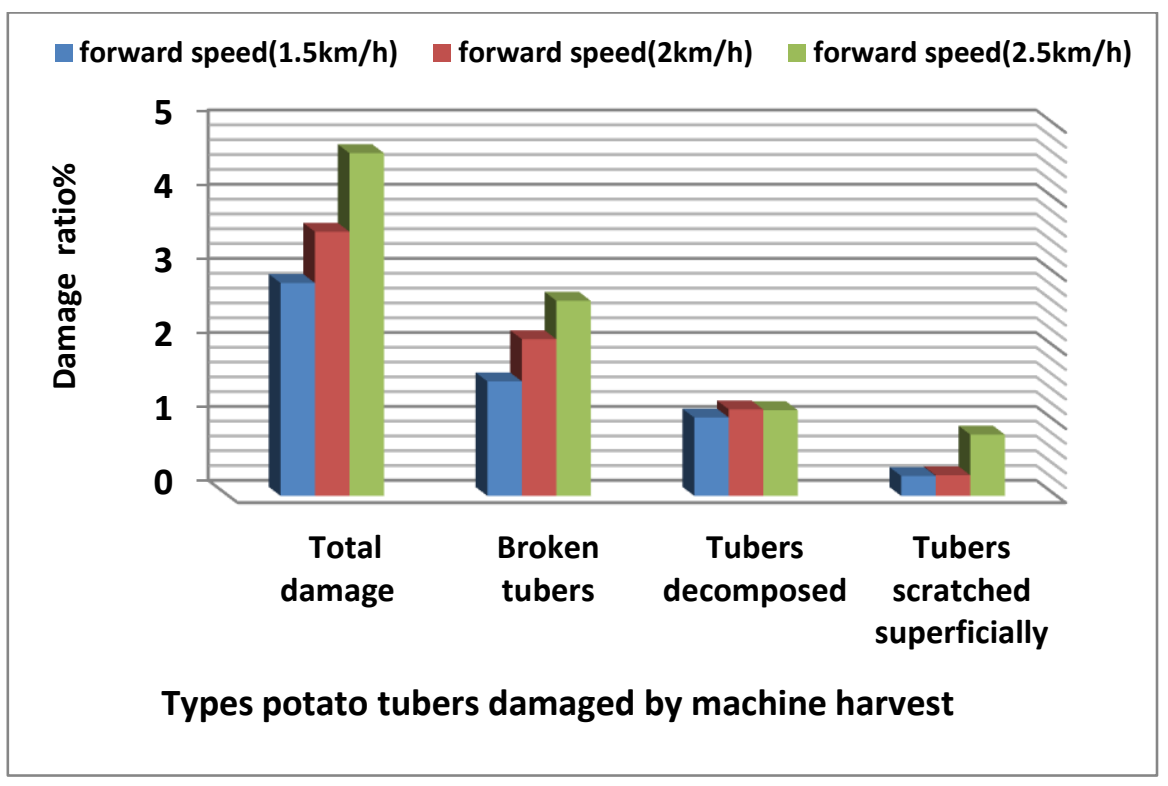

Fig. (4) Effect of the forward speed of the machine on the proportion of Total damage, broken tubers ,Tubers scratched superficially and Tubers scratched superficially 
Fig. (5) shows the effect of the forward speed of the machine on the tubers damage coefficient. It is noted that the value of the damage coefficient ranges between 14.28 for the first speed and 22.78 for the third speed, and the damage coefficient values for the three speeds are less than 100 within the permissible damage rates.

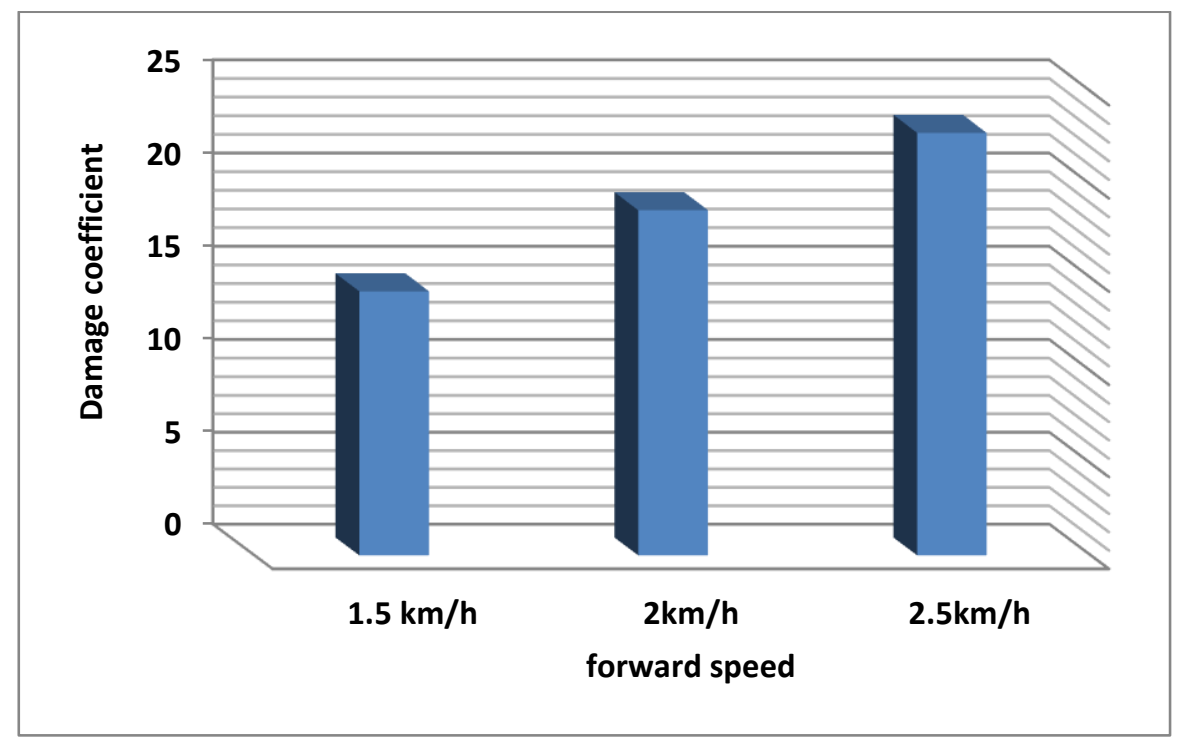

Fig. (5) Effect of the forward speed of the machine on the coefficient of damage of potato tubers

\section{2- Effect of depth of digger on potato tubers.}

Fig. (6) shows the effect of the depth of digger on the quantity of harvested potatoes. It is noted that with the increase in the depth of the cut, the amount of potato shredded increase, and note that there is no effect to the depth of digger $18 \mathrm{~cm}$ and the depth of digger $22 \mathrm{~cm}$ on the amount of potatoes shredded, while the effect of the depth of digger 14 $\mathrm{cm}$ and the rest depths of digger $18 \mathrm{~cm}$ and $22 \mathrm{~cm}$ and 15.36 tons / fed depth of digger $22 \mathrm{~cm}$. This may be due to the fact that the function works at a greater depth of the digger or is equal to depth of digger of the presence of tubers in the field, which increased the amount of harvested potatoes and decreased the amount of potato buried in the soil, which in turn increases the percentage of potatoes. Fig. (6) Also shows the effect of the depth of digger on the amount of buried potatoes in the soil. It is 
noted that with the increase in the depth of digger, the amount of buried potatoes in the soil decreased, the amount of buried potatoes ranging from 0.42 tons / fed at the depth of digger $22 \mathrm{~cm}$ and 4.29 tons / fed at the depth of digger $14 \mathrm{~cm}$ also notice the effect of depth of digger $14 \mathrm{~cm}$ and the rest depths of digger 18 and $22 \mathrm{~cm}$, depth of digger of $18 \mathrm{~cm}$ and depth of digger $22 \mathrm{~cm}$ on the amount of buried potatoes in the soil. Fig. (7) shows the effect of the depth of digger on the Percentage of potato tubers. It is noted that with the increase in the depth of digger, the proportion of the increase increases, resulting in the depth of digger of 22 $\mathrm{cm}$ proportion of $97.25 \%$ while depth of digger $14 \mathrm{~cm}$ resulted in $70.92 \%$ and it is noted that the effect of the depth of digger $14 \mathrm{~cm}$ and the rest depth of digger 18 and $22 \mathrm{~cm}$, There is a depth of digger effect of $18 \mathrm{~cm}$ and a depth of digger of $22 \mathrm{~cm}$ on potato reduction ratio. Fig. (8) Also shows the effect of the depth of digger on the total damage to potato tubers. It is noticeable that increasing the depth of digger from $14 \mathrm{~cm}$ to $22 \mathrm{~cm}$ leads to a decrease in the percentage of total damage, ranging between $8,36 \%$ and $0.49 \%$ and found that the effect of the depth of digger $14 \mathrm{~cm}$ and the rest depths of digger 18 and $22 \mathrm{~cm}$, The depth of digger $22 \mathrm{~cm}$ on the overall damage ratio. Fig. (8) shows the depth of digger of the effect on the proportion of superficial tuberous tubers. It is noticed that increasing the depth of digger from 14 to $22 \mathrm{~cm}$ leads to a decrease in the percentage of superficially tuberous tubers from $0.95 \%$ to $0.04 \%$. The effect of the depth of digger is $14 \mathrm{~cm}$ and the depth of digger is $22 \mathrm{~cm}$. Fig. (8) also shows the effect of the depth of digger on the proportion of tubers. The rate of tubers is reduced by increasing the depth of digger, ranging between $0.24 \%$ at the depth of digger $22 \mathrm{~cm} 2.27 \%$ at the depth of digger $14 \mathrm{~cm}$. To the depth of digger on the tubers. Fig. (8) Shows the effect of depth of digger on the proportion of damage tubers. As shown in the Fig.(8) the proportion of broken tubers decreases with depth of digger, ranging between $0,21 \%$ at the depth of digger $22 \mathrm{~cm}$ and $5.14 \%$ at the depth of digger $14 \mathrm{~cm}$. The depth of digger was $14 \mathrm{~cm}$ and the depth of digger was 18 and $22 \mathrm{~cm}$, while there was no difference between the effect of the depth of digger $18 \mathrm{~cm}$ and the depth of digger $22 \mathrm{~cm}$ on the proportion of broken tubers. 


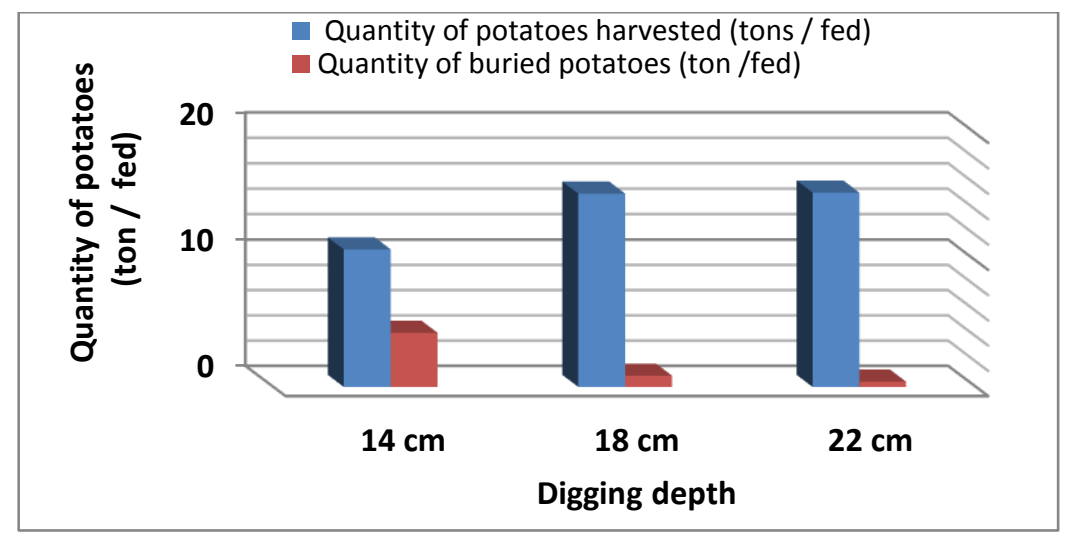

Fig. (6) Effect of the depth of digger on the proportion of potatoes and the amount of buried potatoes in the soil.

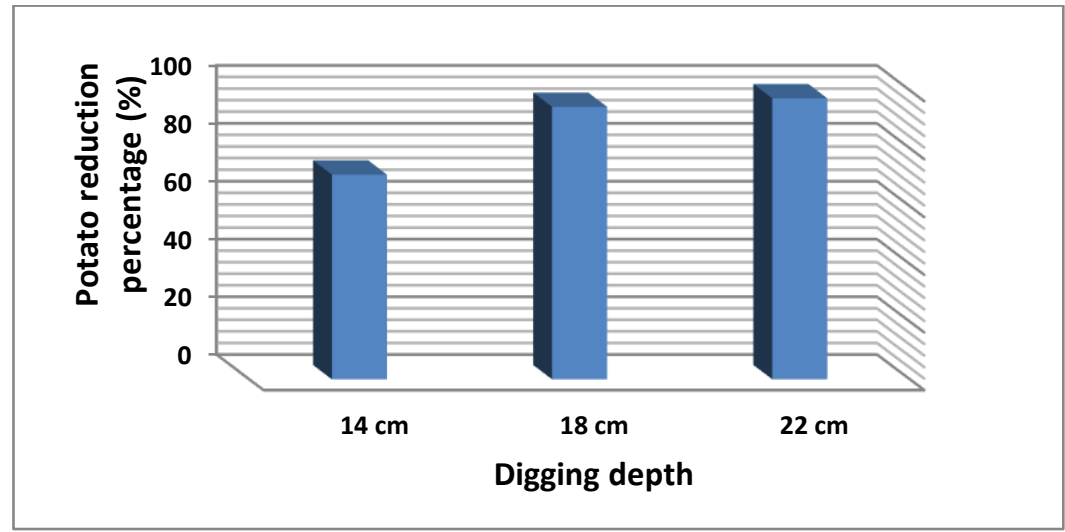

Fig. (7) Effect of the depth of digger on Potato reduction percentage (\%)

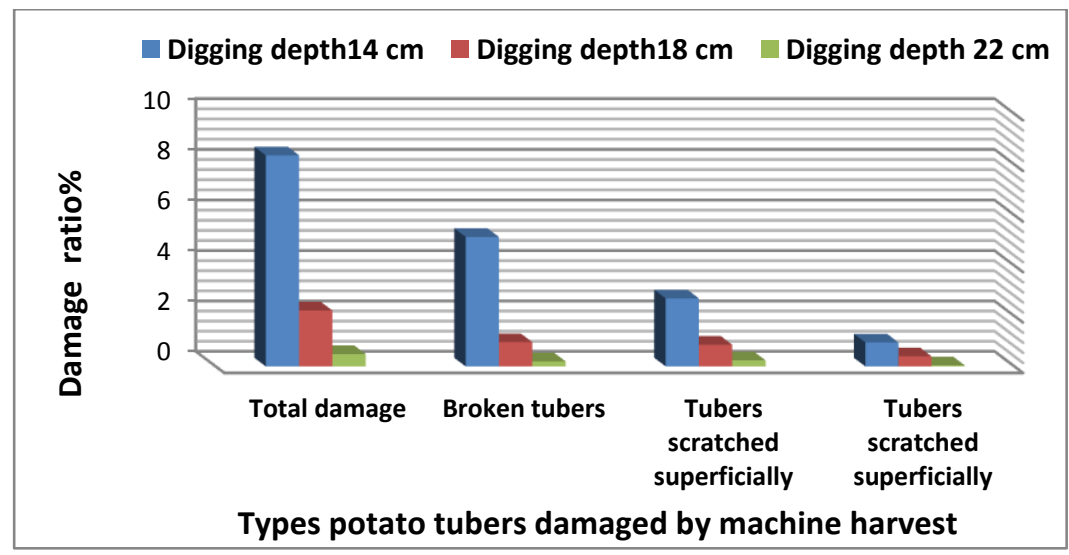

Fig. (8) Effect of the depth of digger on the proportion of Total damage, broken tubers, Tubers scratched superficially and Tubers scratched superficially 
Fig. (9) shows the effect of the depth of digger on the coefficient of damage of potato tubers. However, there is no difference between the depth of digger $18 \mathrm{~cm}$ and the depth of digger $22 \mathrm{~cm}$ on the damage coefficient, while there is a difference between the effect of the depth of digger $12 \mathrm{~cm}$ and the rest depths of 18 and $22 \mathrm{~cm}$. The value of damage coefficient between $2.21 \%$ Depth of $22 \mathrm{~cm}$ and $43.75 \%$ for a depth of 14 $\mathrm{cm}$, and the values of the damage coefficient to the depths of the three diggers within the permissible damage rates as it is less than 100 by classification of the proportion of damage.

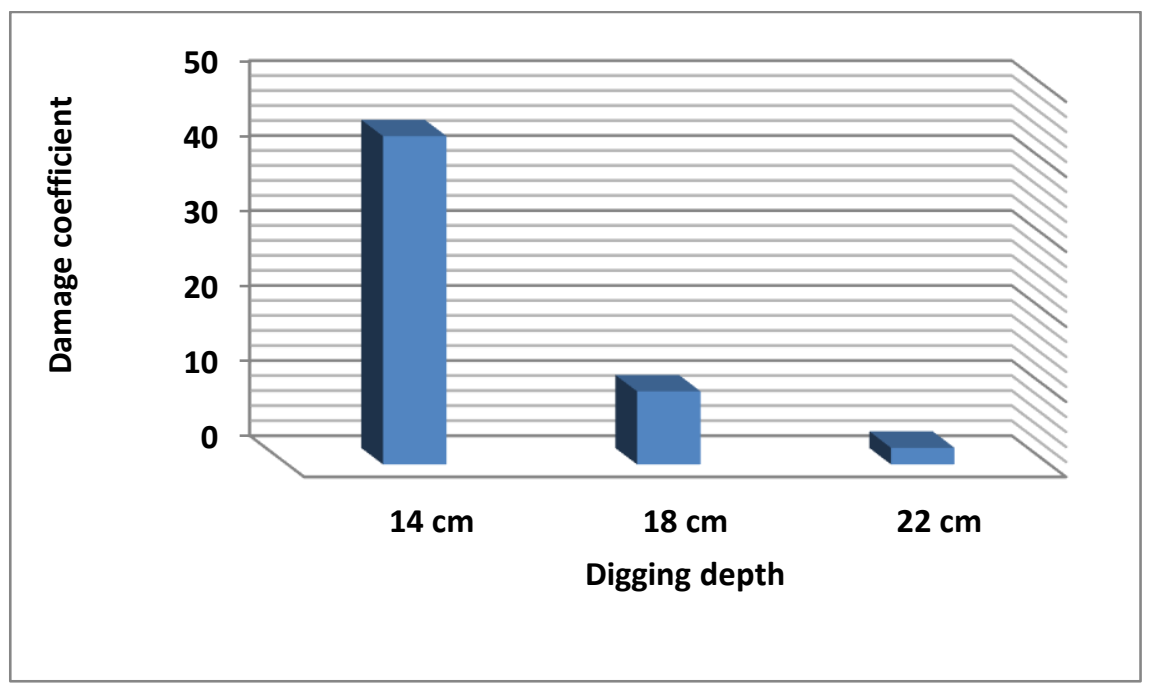

Fig. (9) Effect of the depth of digger on the coefficient of damage of potato tubers.

\section{3- Effect of series vibration frequency amplitude for sieve unit on potato tubers}

Fig. (10) Shows the average amount of harvested and buried potatoes in the soil and the proportion of tuberization of potato tubers at the vibration of the initial series of the screening unit at different pulse rates. Fig. (10) Also shows the effect of the primary chain vibration frequency amplitude on the amount of potato shredded by the machine. Note that with the amplitude of the initial chain vibration frequency, the quantity of the potatoes being cut increases, with the amount of potatoes plucked between 12.45 tons / fed to the capacity of the $20 \mathrm{~mm}$ and 14.43 tons / 
fed at $25 \mathrm{~mm}$. It is noted that there is an effect of the vibration of the initial chain vibration of the screening unit on the quantity of potato shredded by the machine. It is noted that with the amplitude of the vibration of the primary chain vibration, the quantity of potato shredded increases. The amount of harvested potatoes ranged from 12.45 tons / fed to $20 \mathrm{~mm}$ and $14.43 \mathrm{ton} /$ fed for $25 \mathrm{~mm}$. It was found that there was an effect of the vibration of the initial chain vibration of the sifting unit on the quantity of the shredded potatoes. Fig. (10) Shows the effect of initial series vibration frequency on the amount of soil-buried potatoes. Fig. 4,5 shows that with the increase in amplitude, the amount of buried potatoes in the soil is reduced. The amount of buried potatoes in the soil ranged between 1.58 Ton / fed at $25 \mathrm{~mm}$ pulses, 2.15 tons / fed at $20 \mathrm{~mm}$ pulses. As shown in Fig. (11). the effect of the vibration frequency of the automatic chain on the potato reduction ratio is shown. It is noticed from Fig. 4-5 that with the increase in vibration amplitude, the increase ratio is increased. The amplitude of the $25 \mathrm{~mm}$ amplitude is $89.65 \%$. The amplitude is $20 \mathrm{~mm}$, resulting in $85.34 \%$ reduction. Fig. (12) Shows the average percentage of total damage and the ratio of shallow, crushed and crushed tubers to the potato tubers damage coefficient when shaking the initial series of the screening unit with different pulse capacities. Fig.420: the college. Note that with the amplitude of the initial series vibration frequency, the overall damage ratio increases. The total damage rate is $3.24 \%$ for the oscillation capacity of $20 \mathrm{~mm}$ and $4.14 \%$ for the $25 \mathrm{~mm}$ oscillation frequency. Fig. (12) Shows the effect of the vibration frequency of the primary chain on the proportion of superficially tuberous tubers. It is noticed from Figure 4-6 that increasing the amplitude of the oscillation from $20 \mathrm{~mm}$ to $25 \mathrm{~mm}$ leads to an increase in the proportion of tuberous tubers superficially from $0.34 \%$ to $0.58 \%$. Fig. (12) also shows the effect of the vibration frequency of the primary chain on the rate of the tubers. Fig. 4-6 shows that the rate of the tubers was $1.07 \%$ for the $25 \mathrm{~mm}$ and $1.19 \%$ for the pulse frequency of $20 \mathrm{~mm}$. The figure also shows that there is a clear effect of the initial chain vibration amplitude on the proportion of the tubers being decomposed. Fig. (12) Shows the effect of the vibration frequency of the primary chain on the 
proportion of broken tubers. It is noted that when the amplitude of the pulse increased, the proportion of broken tubers increased, and the proportion of broken tubers ranged between $1.71 \%$ and $2.49 \%$ for the pulse of $20 \mathrm{~mm}$ and $25 \mathrm{~mm}$, respectively. Fig. (13) Also shows the effect of initial series vibration amplitude on potato tubers damage coefficient.

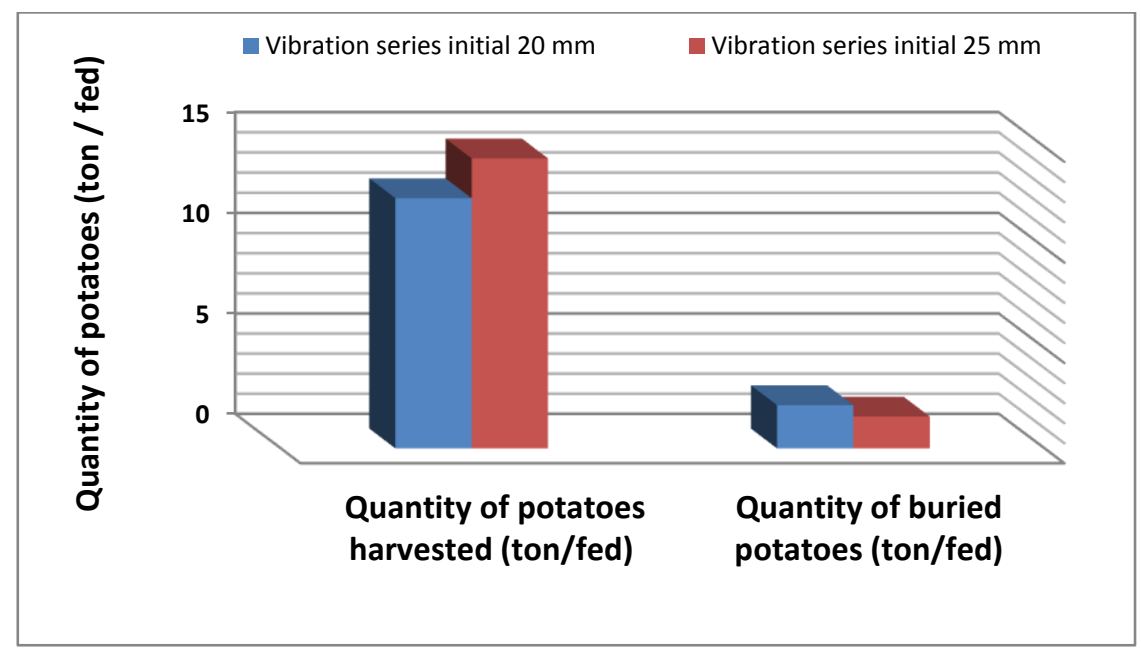

Fig. (10): Effect of the pulse amplitude of the primary series vibration on the proportion of potatoes and the amount of buried potatoes in the soil

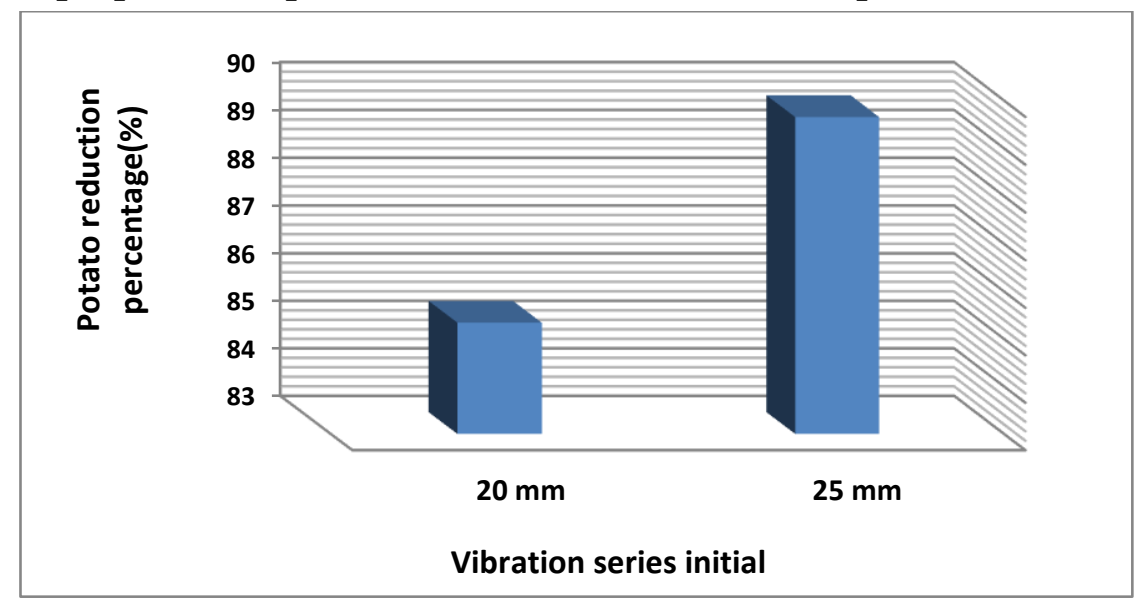

Fig. (11) Effect of pulse amplitude of primary series vibration on Potato reduction percentage $(\%)$ 


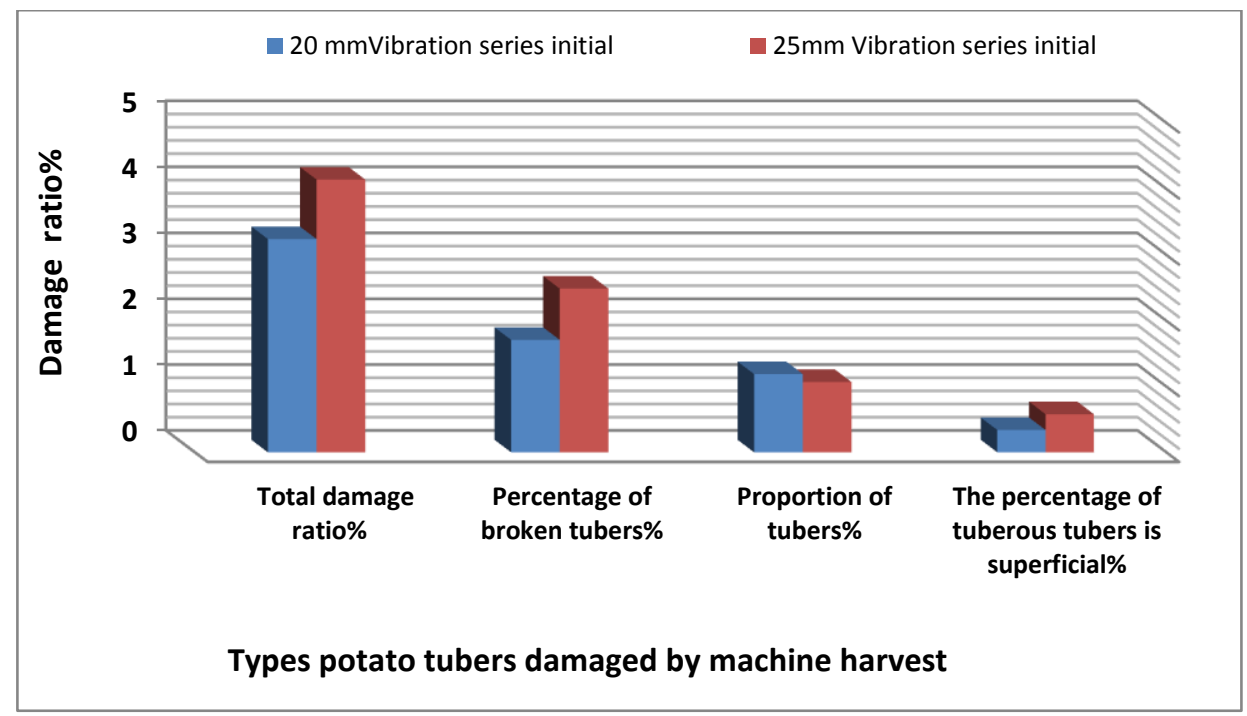

Fig. (12) Effect of pulse amplitude of primary series vibration on the proportion of Total damage, broken tubers, Tubers scratched superficially and Tubers scratched superficially

Fig. (13) Shows that with the increase in the amplitude of the oscillation, the coefficient of damage increases. The damage coefficient varies from 15.89 to $20 \mathrm{~mm}$ and 21.24 to $25 \mathrm{~mm}$. The values of the coefficient of damage for the oscillation range are among the permissible damage rates as they are less than 100 according to the classification of the damage ratio.

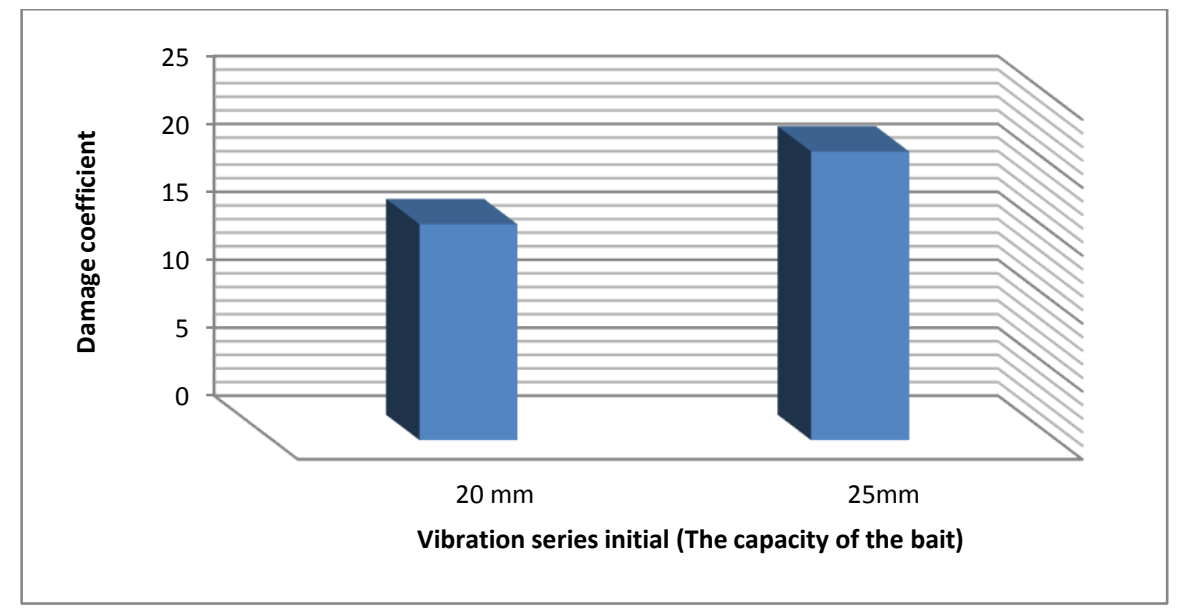

Fig. (13) Effect of pulse amplitude of primary series vibration on potato tubers damage coefficient 


\section{REFERENCES}

Abdel-Aal, S. E., M. S. EL-Shal, M. K. Abdel-Wahab, and A. A. Abdel-Bary.2002. Development of a potato harvester suitable for Egyptain farm. Misr J.Ag Eng. 19 (3): 643 - 656.

Abdel-geleal, M.M.1992. Mechanization of Potato Harvesting in Egyptian Conditions (MA) Mansoura University, Egypt.

Abdel-Maksoud, S. E., M. M. Morad and H. A. Morghany. 2004. Development of a combination unit for harvesting and gathering potato crop. Zagazig J. Agric . Res. 31 (2): 699 - 718

Emam, A. H. 1999. Designed and developed suitable sweet potato harvester for Egyptian farms.Ph.D. Th., Agric. Eng. Dept., Fac. Of Agric. Zagazig Univ. Egypt.

International organization For Standards handbook - Agriculural machinery.1983. Equipment For planting - potato planters Method of testing,5691-1981(E).

Sayed. M. S.. A. M. Mahmoud M. A. Abdel -Maksoud and M.F. Fahd 1996. An engineering study on a prototype digger for potato harvesting.Misr J. Agric. Eng. 13(1):245-261.

Vatsa, D. K., T. C. Thakur and B. Singh. 1993. Effect of speed and shape of shares on performance of oscillatory sieve potato digger. A. M.A. 24 (4): $51-56$.

أبو حباجة مصطفى م ـ، وسليمان ع ـ اليحيى 99 9 و ام ـ التطبيقات العملية فى الآلات الزر اعية. مطبعة جامعة المنصورة ، جمهورية مصر العربية .

إسماعيل ،زكريا إبراهيم ـ ـ9 9 ام ـ محصول البطاطس ( الزر اعة ،الحصاد ،التخزين ). منشأة المعارف بالأسكندرية ، جمهورية مصر العربية العربية .

السعدون ،عبد اللّه عبد الرحمن. 199 ام ـ محصول البطاطس فى المملكة العربية السعودية

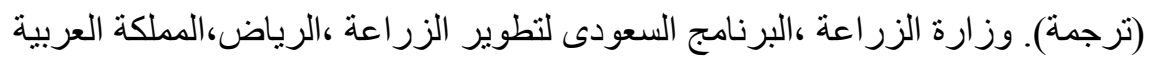
السعودية . 


\section{الملخص العربحي \\ بعض العوامل المؤثرة على تلف درنات البطاطس عند الحصاد \\ " دمال كمال عرفه}

تم فى هذا البحث در اسة تأثير بعض العو امل التي تؤثر على تلف درنات البطاطس أثناء الحصاد

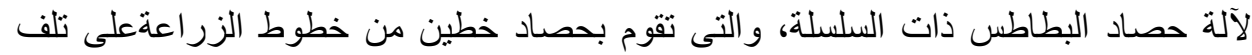

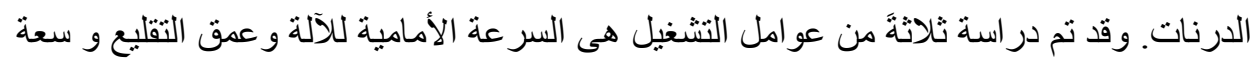

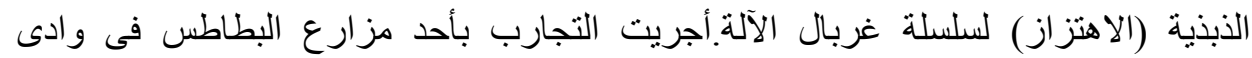

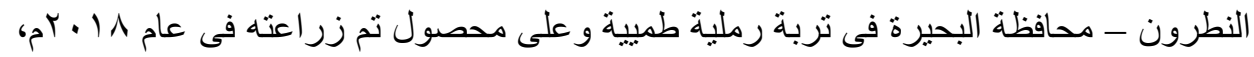
و البطاطس التى تم عليها الدراسة هى من صنف كنج ادوارد ذات الثكل البيضاوى. أظهرت النتائج أن السرعة الأمامية لحصاد البطاطس لا يوجد لها تأثير كبير على رفع درنات البطاطس التس

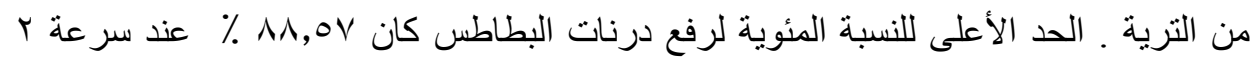

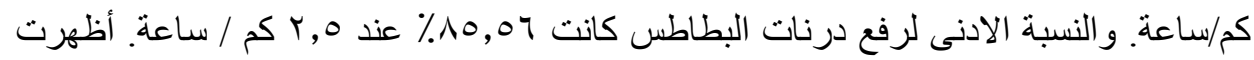

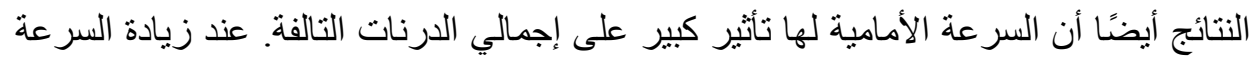

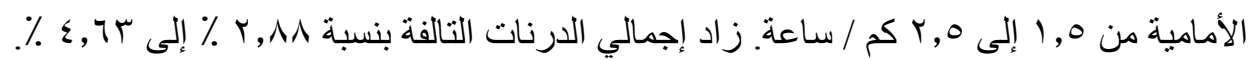

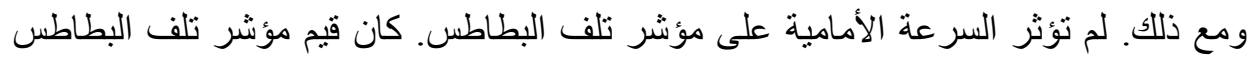

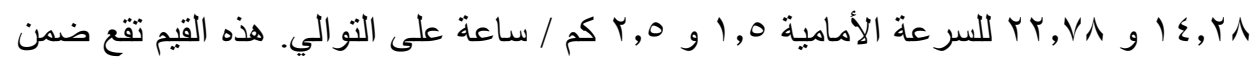

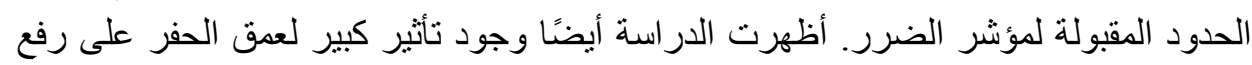

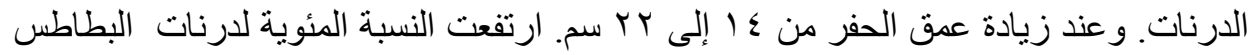

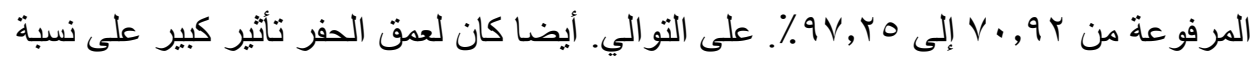

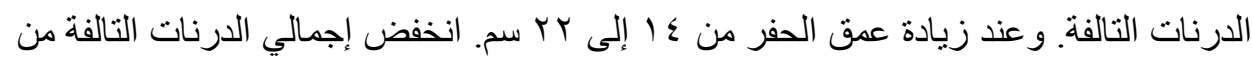

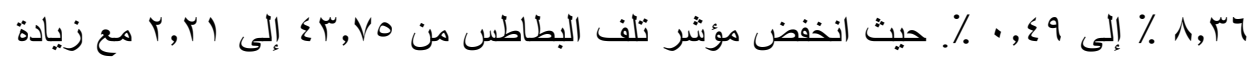
عمق الحفر من \& ا إلى ب r سم. هذه القيم لمؤشر تلف البطاطس تقع ضمن الحدود المقبولة

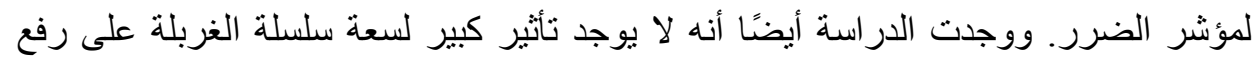

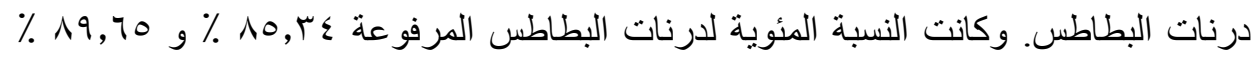
لسعة . r و T T مح على التو الي. أيضا لا يوجد هنالك تأثير كبير لسعة سلسلة الغربلة على إجمالي

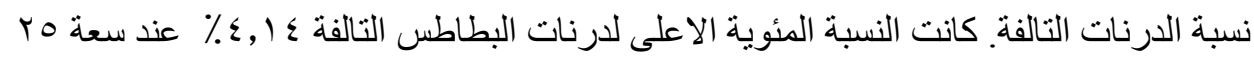

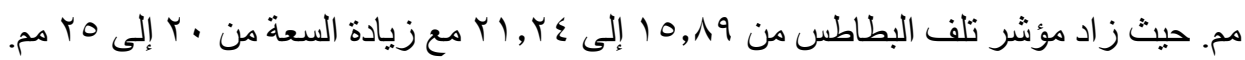

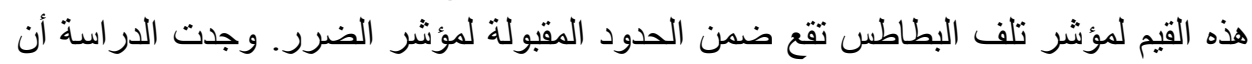

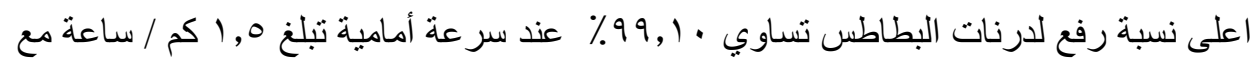

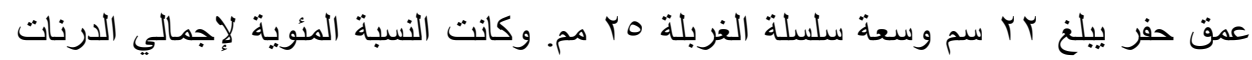

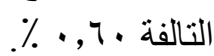

* باحث أولـ معهد بحوت الهندسة الزراعية ـ مركز البحوث الزراعيةـ مصر 


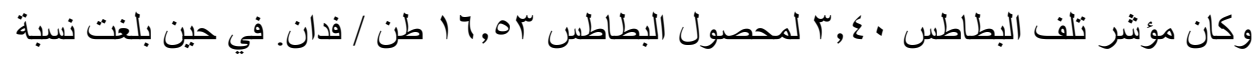

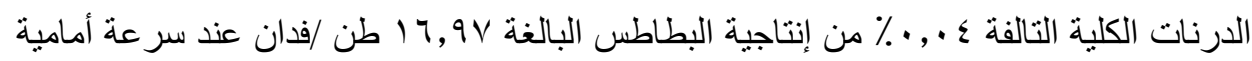

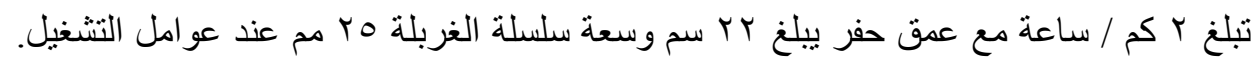

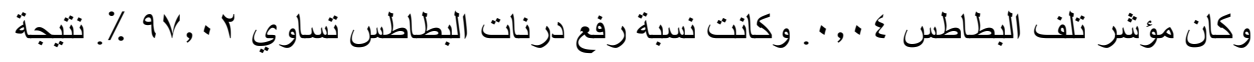

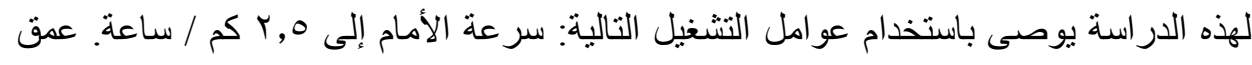

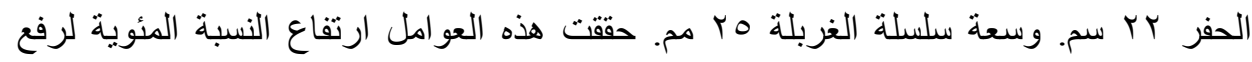

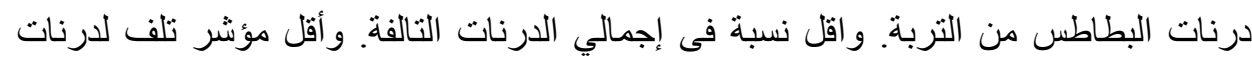
البطاطس. 